\title{
Best Practice Program for Low-Income African American Students Transitioning from Middle to High School \\ Carolyn Gentle-Genitty
}

\begin{abstract}
On the basis of systematic evaluation of three program databases, totaling 246 programs, this article provides a discussion on a best practice program for low-income African American students transitioning from middle school to high school in urban school settings. The main research question was "Of the programs touted as best practice, is there one that could produce positive middle school transition outcomes for low-income African American students in urban school settings?” To allow for the examination of as many programs as possible that targeted African American students, no subcategories of African American students were made, for example, low income. Using specific exclusion criteria, the author chose four programs as best practice (School Transitional Environmental Program [STEP]; Skills, Opportunity, and Recognition; Positive Action through Holistic Education; and Fast Track). These four programs were further evaluated with an eight-point inclusion criteria. The results suggested that STEP was the best best practice program, from those examined, for working with low-income African American transitioning from middle school to high school.
\end{abstract}

Key words: African American students; best practice; high school; middle school; transition

This is the author's manuscript of the article published in final edited form as:

Gentle-Genitty, C. (2009). Best Practice Program for Low-Income African American Students Transitioning from Middle to High School. Children \& Schools, 31(2), 109-117. https://doi.org/10.1093/cs/31.2.109 
This is the author's manuscript of the article published in final edited form as:

Gentle-Genitty, C. (2009). Best Practice Program for Low-Income African American Students Transitioning from Middle to High School. Children \& Schools, 31(2), 109-117. https://doi.org/10.1093/cs/31.2.109 
Literature on dropping out of school often focuses on high school, yet by the end of the 10th grade more than six percent of students drop out of school (Mizelle, 1999). Many of these students are simply unable to transition successfully from middle school to high school. African Americans, as compared with their peers, have greater decreases in grades following school transition (Simmons et al., 1991). Akos and Galassi (2004) found that African American students experienced greater declines in grade point averages (GPAs) and were branded with more labels by teachers and peers than were their counterparts. These students go on to dislike school, become truant, and experience increases in disciplinary problems in and out of school, eventually dropping out (Osterman, 2000). Therefore, finding programs that enhance protective factors enabling low-income African American students to transition effectively is a must (Clark, 1991; Gutman \& Midgley, 2000). This article shares results of a systematic review of three best practice databases to try to identify one or more best practice programs that could aid African American students in the transition from middle to high school.

Background Though the focus of this article is on African American students, the transition from middle school to high school can be difficult, challenging, and uncertain for all children (Johnstone, 2002). In early adolescence (Smith, 1997) students experience physical, psychological, and cognitive changes and are considered still financially dependent upon their parents, their needs are gratified by their peers, and their expected roles, as they move from childhood to adulthood,

This is the author's manuscript of the article published in final edited form as:

Gentle-Genitty, C. (2009). Best Practice Program for Low-Income African American Students Transitioning from Middle to High School. Children \& Schools, 31(2), 109-117. https://doi.org/10.1093/cs/31.2.109 
are very murky and confusing (Wattenberg, 1974). At the same time that students face these changes, they also experience changes in their school environment, such as changes in teachers, peer groups, class size, and school location, and from small-group and individualized methods of instruction to whole class lectures (Alspaugh, 1998; Newman, 2000). All of this occurs during adolescence, when the student needs stability (Blyth, Simmons, \& Bush, 1978; Rice, 2001). The result can be a feeling of "not belonging” and reminiscing about moving from supported elementary schools to fragmented middle and high schools (Eccles, Lord, Roeser, Barber, \& Jozefowicz, 1999). Simmons and colleagues are credited as founders of the study in school transition research beginning in Milwaukee in the late 1970s (Blyth et al., 1978; Seidman, Allen, Aber, Mitchell, \& Feinman, 1994; Simmons \& Blyth, 1987).

African American students have academic challenges bounded by achievement gaps resulting in school failures, truancy, lower self-esteem and coping skills, and identity formation challenges (Cashin, 2004; Gentle-Genitty, 2008; Roderick, 2003). With multiple risk factors in different domains—individual, peer group, family, community, and school—low-income African American students are more at-risk to not transition effectively (Smith, Lizotte, Thornberry, \& Krohn, 1995). Risk factors are factors within a child's environment that directly or indirectly affect or increase the probability of harm (Fraser, 2004). The risk factors for low-income African American students are compounded when African American students are in an urban school

This is the author's manuscript of the article published in final edited form as:

Gentle-Genitty, C. (2009). Best Practice Program for Low-Income African American Students Transitioning from Middle to High School. Children \& Schools, 31(2), 109-117. https://doi.org/10.1093/cs/31.2.109 
setting, experience differences in behavioral patterns and discipline, and have variations in language, expression, and emotional drive (Clark, 1991; Hale-Benson, 1986).

Although many of the challenges may have existed prior to the middle school transition, they are exacerbated during the school transition. These challenges may include "living in poverty; experiencing dramatic declines in support and quality of relationships; and having negative school experiences” (Roderick, 2003, pp. 543-546). Others may include disruptions in individual belief in self and functioning, family, school, peer networks, and community (Johnstone, 2002, Roderick, 2003). Indeed, the period of middle to high school transition epitomizes the point where the recently described "school-to-prison pipeline” is created (Richart, Brooks, \& Soler, 2003). Phillips (2006) wrote that of every 10 black men in prison in 2004, six were school dropouts.

In general, there is a lack of programs in most areas related to dropout prevention that specifically target the middle school population. Students who do not adjust well to the transition to high school often substitute school values with unconventional values of crime and delinquency and find themselves dropping out before there are ways for them to adequately get back in (Barton, 2005). Currently, there are no programs, at the middle school level, for students who dropout, to get back in school. Many students simply engage in various activities until they are old enough to sit for the general education diploma exam and formally get back into the school system (Barton, 2005; Gentle-Genitty, 2008).

This is the author's manuscript of the article published in final edited form as:

Gentle-Genitty, C. (2009). Best Practice Program for Low-Income African American Students Transitioning from Middle to High School. Children \& Schools, 31(2), 109-117. https://doi.org/10.1093/cs/31.2.109 
For low-income African American students, ineffective transition results in a behavioral pattern of socialization, financial stress, and family dysfunction as compared with the mainstream culture (Irvine, 1990; Taylor, 1991).

Evidence-based practice is a decision-making tool that amalgamates practice wisdom and external research evidence with target group needs to effect the best positive change (Gibbs \& Gambrill, 1999). Researchers have suggested that best practice programs for students transitioning from middle school to high school must be comprehensive, build a sense of community, increase school connectedness, increase social networks and family involvement, increase a sense of responsibility for learning and decision making, and have trained teachers who can meet these demands (Akos \& Galassi, 2004; Weldy, 1995). The National Center on Youth Transition (2006) adds that the program must teach the student to be autonomous, educated, and productive. In addition, programs must be culturally sensitive to the needs of lowincome African Americans and build problem-solving and cognitive skills, confidence, competence, and self-esteem (Seidman et al., 1994). Together these are signs of students transitioning effectively and serve as the measure of evidence of the best practice program for working with this population.

The research question to guide the exploration was "Of the programs touted as best practice, is there one that shows promise to produce positive middle school transition outcomes for low-income African American students?” For purposes of this review the target population

This is the author's manuscript of the article published in final edited form as:

Gentle-Genitty, C. (2009). Best Practice Program for Low-Income African American Students Transitioning from Middle to High School. Children \& Schools, 31(2), 109-117. https://doi.org/10.1093/cs/31.2.109 
was defined as low-income African American students transitioning from middle to high school in an urban setting. This target population was not broken down by gender, family, parental makeup, seriousness of at-risk behaviors, or other such categorization. This strategy allowed for the examination and evaluation of as many programs as possible.

Method

Researchers often use systematic reviews to gather evidence about best practices. In support of evidence-based practices, various Web-based collections of "best practices” are now available, but not all programs included in such databases have been rigorously tested. Three databases that included programs broad enough to be useful in a school setting were selected. Criteria to screen and then assess available studies were used according to the process set out by the Evidence for Policy and Practice Information (EPPI-Centre) for non-quantitative reviews search, screen, describe, map and refine and appraise and synthesize (EPPI-Centre, 2006).

Evidence-based practice is also known as a process of weeding out the best evidence to support practice (Gibbs \& Gambrill, 1999). First, a search was conducted for programs that were defined as a best practice within a particular field, were age-specific — If the age was defined as a range, the range must include students 13 to 14 years old; were implemented in an urban school setting - if multiple locations were suggested, an urban setting had to be one of the locations; and indicated that the program worked specifically with students in transition. This process entailed using different online databases, search engines (Internet search for websites etc.), and library

This is the author's manuscript of the article published in final edited form as:

Gentle-Genitty, C. (2009). Best Practice Program for Low-Income African American Students Transitioning from Middle to High School. Children \& Schools, 31(2), 109-117. https://doi.org/10.1093/cs/31.2.109 
resources to find programs. The result was that three databases appeared to focus on programs that were applicable to the school setting —Catalano and colleagues's (1998) positive youth development database (25 programs), the Office of Juvenile Justice Delinquency Prevention’s (OJJDP) (n.d.) Model Program on juvenile justice (194 programs), and the Office of the Surgeon General (2001) (27 programs); together totaling 246 programs.

Exclusion Criteria. The exclusion criteria specified that programs would be excluded if they had not identified African American students as one of their target populations, provided insufficient information for evaluation or no studies were conducted on it, designed primarily for developmentally disabled/disability populations in transition, addressed students in transition from residential facilities, and showed strong evaluation design but no effect on the population.

Inclusion Criteria. Once programs that did not meet the criteria for further review were excluded, inclusion criteria were applied to qualitatively assess for best practice. Although reviews sometimes use quantitative meta-analytic criteria, the programs and evaluation methods used did not lend themselves to this method. The inclusion criteria was only for those programs that met all seven criteria: (1) Outcome: whether there was a reduction of problem behavior or increase in positive behavior; (2) Domain: whether more than three or all five domainsindividual, peer, family, school, and community_were addressed (Akos \& Galassi, 2004; Weldy, 1995); (3) Curriculum: whether a structured curriculum or activity format was used (so that it would be easier for school social workers to replicate); (4) Frequency and Duration:

This is the author's manuscript of the article published in final edited form as:

Gentle-Genitty, C. (2009). Best Practice Program for Low-Income African American Students Transitioning from Middle to High School. Children \& Schools, 31(2), 109-117. https://doi.org/10.1093/cs/31.2.109 
whether the program lasted nine months or more (most programs listed on best practice sites are at least six months in duration); (5) Program Strategies: whether the program addressed cognitive-behavioral skill (decision-making skill, self-concept, competence, self-esteem) and social skill (coping, refusal, self-management skills) development (Geenen, Powers, \& LopezVasquez, 2001; National Center on Youth Transition, 2006; Seidman et al., 1994); (6) Implementation Assurance: whether the program has procedures for fidelity, and (7) Methodology: whether the program evaluation methods used reliable or rigorous methods for pre- and post-testing and quasi or experimental designs with assigned comparison groups.

Results

After the initial screen, 246 programs were located that met the initial screening criteria. After applying the inclusion criteria, 242 were excluded, leaving the following four programs to undergo further review for the best practice program: (1) School Transitional Environmental Program (STEP); (2) Skills, Opportunity, and Recognition (SOAR), formerly Seattle Social Development Project; (3) Positive Action through Holistic Education (Project PATHE), and (4) Fast Track. The results of applying the inclusion criteria are presented in Table 1.

Programs Summary

STEP

STEP targets primarily nonwhite low-income students in transition from elementary and middle school high schools in urban areas.

This is the author's manuscript of the article published in final edited form as:

Gentle-Genitty, C. (2009). Best Practice Program for Low-Income African American Students Transitioning from Middle to High School. Children \& Schools, 31(2), 109-117. https://doi.org/10.1093/cs/31.2.109 
Program Strategies. The program strategies include the following: identifying students in the STEP program, identifying students enrolled in the same core classes, and assigning students to homeroom classrooms with similar STEP enrollment and core classes. Because the structure or format of the program was shared with teachers, administrator, parents, and students, they were all invested to see each component instituted and thus served as their own "implementation assurance” for fidelity. The program caters to both boys and girls, with the expectation to “decrease student anonymity, increase student accountability, and enhance student abilities to learn school rules and exceptions” (Felner et al., 1993).

Frequency and Duration. The program was offered for the entire academic calendar. Thus it meets the criteria of nine months of more.

Curriculum. The program uses the school's already established and structured curriculum to work with students in their school setting. Because the program works with teachers, who act as guidance counselors and administrators; other STEP participants, such as peer groups in the same classes; parents who are kept abreast of their child's progress and asked to participate in planning class schedules; and individual students to help them to improve their academics and socialization skills and create new support systems and networks, the STEP program works effectively in all five domains of the child's life (Felner et al., 1993; OJJDP, n.d).

Evaluation. This program has been hailed as an effective program by OJJDP. A five-year longitudinal quasi-experimental study design was used to evaluate the STEP program $(n=$

This is the author's manuscript of the article published in final edited form as:

Gentle-Genitty, C. (2009). Best Practice Program for Low-Income African American Students Transitioning from Middle to High School. Children \& Schools, 31(2), 109-117. https://doi.org/10.1093/cs/31.2.109 
1,965). Of the total students, 1,205 were in the STEP program and 761 were in comparison groups. As students transitioned from sixth grade to junior high and from seventh grade to high school, pretest data were collected and after one year, data were collected again. Data on school transition stress, psychological distress, behavior problems, academic expectations, and classroom behavioral adaptations were collected (Felner et al., 1993). The results showed that as compared to the comparison group, students in the STEP program showed significantly lower levels of school transition stress; were better adjusted to school, family, general self-esteem, depression, anxiety, and delinquent behaviors; and had high levels of academic expectations. STEP students had better classroom adjustment behavior and significantly better grades and attendance patterns. At the ninth-grade evaluation, STEP students had fewer absences, increased GPAs, stronger self-concept and competence, positive feelings about school, and perceptions of school being more stable, supportive, organized, and involved. Long-term evaluation has suggested fewer dropouts of STEP students (Felner et al., 1993; OJJDP, n.d).

SOAR

The SOAR program, formerly Seattle Social Development Project, is a multidimensional program. SOAR targets primarily five- to 14-year-old boys and girls, ethnic varied, high-risk, low socioeconomic, low-school achievement middle school children. The program uses parent and teacher training to effect change in the students. SOAR's goal is to decrease problem behaviors, intervene early with work with parents, teachers, and children to increase positive and

This is the author's manuscript of the article published in final edited form as:

Gentle-Genitty, C. (2009). Best Practice Program for Low-Income African American Students Transitioning from Middle to High School. Children \& Schools, 31(2), 109-117. https://doi.org/10.1093/cs/31.2.109 
supportive bonds, and strengthen attachment and commitment to school (Huang, Kosterman, Catalano, Hawkins, \& Abbott, 2001; OJJDP, n.d)

Program Strategies. The program recruits first- and sixth-grade teachers, and instructs them in classroom management, interactive teaching, and cooperative learning in general. The program then instructs first-grade teachers on communication, decision-making, negotiation, and conflict-resolution skills and instructs the sixth-grade teachers on refusal skills. The students get to work in small, diverse groups to build social skills and positive interaction with pro-social peers (Huang et al., 2001). Parent training is a second component of the program, in which parents are invited to voluntarily participate in training programs throughout the child's schooling. If parents choose to participate, when their children are in first and second grades the parents get to take part in seven sessions of family management, monitoring children, and providing consistent and appropriate discipline. When their children are in second and third grades, parents receive training in four sessions in communication skills, creating positive home learning environments, developing reading and math skills, and supporting their child's progress. In fifth and sixth grades a final five sessions are offered to create, for the family, a stance on drugs and how to encourage refusal skills (Huang et al., 2001; OJJDP, n.d.). The program assumes that through teacher and parent teaching the by-products will directly affect the child and his or her behaviors.

This is the author's manuscript of the article published in final edited form as:

Gentle-Genitty, C. (2009). Best Practice Program for Low-Income African American Students Transitioning from Middle to High School. Children \& Schools, 31(2), 109-117. https://doi.org/10.1093/cs/31.2.109 
Curriculum. The SOAR program has a well-structure curriculum. As outlined earlier, the program is detailed and structured for the teachers, parents, and students in terms of what is offered, when, and to whom.

Domains. Because of the interaction with parents, students, and teachers, only three domains are directly affected by the SOAR program efforts - family, peers, and school.

Evaluation. It is assumed that through constant and consistent training of parents, parents will increase effective communication between teachers and the student and themselves. In addition, consistent parent training will help foster a better positive home learning environment to boost math and reading skills and to support progress (Huang et al., 2001; OJJDP, n.d.,). Since 1985, the SOAR program continues to be evaluated by using a longitudinal pre-experimental design with comparison groups in five schools $(n=808)$. The first intervention groups received the full intervention package described earlier, beginning in first grade and ending in sixth grade. The second intervention group received the intervention in fifth and sixth grade only. The control group did not receive any intervention. Throughout the evaluation, to check for fidelity of the program, the researchers observed the teachers for 50 minutes on two days, one in each semester of each academic year. Data were gathered from multiple system questionnaires, achievement tests, and school records (Huang et al., 2001). The results suggested that students in the intervention group had stronger commitment to school, increases in academic achievement, and decreases in negative behaviors. The full intervention group decreased violent acts by 11.4

This is the author's manuscript of the article published in final edited form as:

Gentle-Genitty, C. (2009). Best Practice Program for Low-Income African American Students Transitioning from Middle to High School. Children \& Schools, 31(2), 109-117. https://doi.org/10.1093/cs/31.2.109 
percent and alcohol use by 10.3 percent. The program reported a significantly better effect, with poor children showing an increase in school attachment and a reduction in grade repetition. The benefits of the program were evident up to the age of 21 years (Huang et al., 2001; OJJDP, n.d.). Project PATHE

The PATHE program caters to 11- to 18-year-old minority, multiethnic students (mainly low-income African American students) in urban school settings, in middle school, and transitioning to high school. PATHE is a comprehensive program offering extracurricular activities, peer counseling, school pride campaigns, job-seeking skills programs, career exploration and attainment assistance within the school system. At-risk students have the added resource of monitoring, tutoring, and counseling. The goal of the PATHE program is to change behavior, improve social bonding and academic achievement, and enhance the view of one’s self. PATHE has five major components: (1) staff, student, and community participation in planning; (2) organizational changes aimed at increasing academic performance are implemented throughout the school; (3) schoolwide organizational changes aimed at enhancing the school climate; (4) programs to prepare students for careers; and (5) academic and affective services for high-risk youths (Catalano, Loeber, \& McKinney, 1999; OJJDP, n.d.). The major assumption is that the program will reduce behavioral disruptions, enhance student attitude toward schools, and increase positive experiences in the school environment. The improved environment helps to decrease failure and increase bonding and individual self-concepts (Catalano et al., 1999).

This is the author's manuscript of the article published in final edited form as:

Gentle-Genitty, C. (2009). Best Practice Program for Low-Income African American Students Transitioning from Middle to High School. Children \& Schools, 31(2), 109-117. https://doi.org/10.1093/cs/31.2.109 
Program Strategies. The program focuses on school organizational culture and student developmental needs concurrently; enhances extracurricular activities; increases peer counseling, job-seeking skills, career exploration programs, mentoring, tutoring, and counseling services; and (4) organizes school pride campaigns (Catalano et al., 1999). On the basis of this description, it is clear that the program meets the criteria of being involved in at least four domains of the student's life—individual, peer, school, and community.

Frequency and Duration. It is unclear how long participants are allowed to be enrolled in the program or whether the program is on a rolling recruitment basis. Thus the criterion of offering the program for a minimum of nine months or more was not adequately met.

Implementation Assurance. No measure attested to whether the program was consistently being monitored by one or more entities to ensure it was being implemented as designed. The criterion of implementation assurance was not met.

Evaluation. The program was evaluated using a quasi-experimental design with four intervention middle schools, one comparison middle school, three intervention high schools, and one comparison high school. The survey periods were 1981, 1982, and 1983 with a sample of 300 students (Catalano et al., 1999; OJJDP, n.d.). Most participants in the study were African American students from rural and urban school settings. The evaluation results found that students in the intervention groups, both in middle and high schools, had greater decreases in engagement in negative behaviors and in grade repetition than the control groups. The results

This is the author's manuscript of the article published in final edited form as:

Gentle-Genitty, C. (2009). Best Practice Program for Low-Income African American Students Transitioning from Middle to High School. Children \& Schools, 31(2), 109-117. https://doi.org/10.1093/cs/31.2.109 
showed increases in grades and graduation rates for those in high school. At-risk students who participated in tutoring, mentoring, and counseling services did significantly better than those who did not participate in these programs. School attachment increased, and school alienation decreased overall in both middle and high schools among students in the intervention groups (Catalano et al., 1999; OJJDP, n.d.).

Fast Track

Fast Track is a comprehensive, all inclusive, long-term, social development program. Fast Track operates in both rural and urban settings, catering to multiethnic groups of five- to 15-year-old students—-from kindergarten to 10th grade—and increasing interventions during school entry or transition times.

Curriculum. The PATHS (Promoting Alternative Thinking Strategies) curriculum is closely used in this program; therefore, Fast Track meets the criterion of having a structured curriculum. Fast Track’s program targets children in kindergarten exhibiting disruptive behaviors.

Domains. The program works within the individual, peer, family, and school domains to enhance problem-solving, cognitive and social skills, and peer relationships and to decrease school or family unwanted behaviors. Fast Track uses a developmental approach to prepare students for transitions through the school years, enhancing programs on the basis of severity of need and behavior (Conduct Problems Prevention Research Group, 2002).

This is the author's manuscript of the article published in final edited form as:

Gentle-Genitty, C. (2009). Best Practice Program for Low-Income African American Students Transitioning from Middle to High School. Children \& Schools, 31(2), 109-117. https://doi.org/10.1093/cs/31.2.109 
Program Strategies. The PATHS curriculum was adopted and revised for use in this program. The program follows a model that offers groups for parents, child social-skills training, academic tutoring, and home visits. These aspects are intensified at the points of school transition and entry (Conduct Problems Prevention Research Group, 2002; OJJDP, n.d.). The program assumes that problem behaviors stem from the multiplicative effect of school, home, and the individual. It believes that if there is change in these areas children will increase communication and bonds with parents and teachers. By enhancing cognitive, social, and problem-solving skills students increase positive peer relations and decrease disruptive behaviors at home and school (Conduct Problems Prevention Research Group, 2002).

Frequency and Duration. Despite the study of the program running for 15 months, the duration and frequency of the program varied. But based on what was assessed students did stay in for a minimum of 15 months. Therefore the criterion for frequency and duration was met.

Implementation Assurance. There was not clear method or strategy identified to assess whether the program designers monitored if their program was being implemented as they had developed. Thus, with no clear indication the implementation assurance criterion could not be assessed and not met.

Evaluation. Fast Track was evaluated by using an experimental design with $(n=891)$ kindergarten students at high risk of conduct disorder. Four sites were chosen for the assessment. Schools were divided into two and matched on free lunch recipient, ethnicity, and standardized

This is the author's manuscript of the article published in final edited form as:

Gentle-Genitty, C. (2009). Best Practice Program for Low-Income African American Students Transitioning from Middle to High School. Children \& Schools, 31(2), 109-117. https://doi.org/10.1093/cs/31.2.109 
scores. Parent and teacher ratings of child's level of risk and disruptive behaviors were combined and the top 10 percent of students were asked to participate in the Fast Track program. Students were randomly assigned to two groups: (1) an intervention group consisting of 445 first graders and (2) a control group consisting of 446 first graders. There were no significant differences between the groups. Fifty percent of the sample were African American (Conduct Problems Prevention Research Group, 2002; OJJDP, n.d.). The evaluation was conducted after 15 months in the Fast Track program. The result was that there were significantly lower rates of disruptive behaviors, aggressiveness, and disobedient behaviors in the intervention group. Parents reported less physical punishment as well, following intervention. Overall, students had increases in positive behaviors and more social problem-solving skills (Conduct Problems Prevention Research Group, 2002; OJJDP, n.d.).

Synthesis. Following review of the four programs, the STEP program emerged as most promising. Only STEP addressed all five domains of interest, actively involving teachers, parents, peers, the individual, and changes in the school community. The program is designed to build a sense of community, increase school connectedness, increase social networks and family involvement, increase the sense of responsibility for learning and decision making, and train teachers to be able to meet these demands (Akos \& Galassi, 2004; Legters \& Kerr, 2001; Osterman, 2000; Weldy, 1995. It was also the only program that was described as working largely with low-income students, primarily African American students. The program was

This is the author's manuscript of the article published in final edited form as:

Gentle-Genitty, C. (2009). Best Practice Program for Low-Income African American Students Transitioning from Middle to High School. Children \& Schools, 31(2), 109-117. https://doi.org/10.1093/cs/31.2.109 
designed to be culturally sensitive and included problem-solving, cognitive, and self-esteem skill development (National Center on Youth Transition, 2006; Seidman et al., 1994). Although STEP best met the criteria for identifying a best practice approach for low-income middle school African American students, SOAR and PATHE could be considered promising. However, SOAR would have to be adjusted to address, more specifically, the target population and to work with middle school students rather than elementary school students. PATHE is ready to be used with low-income African American students transitioning from middle school, but it did not address all five domains, which means that students may be getting support in one domain, such as school and peer group, and not in another, such as family and community, resulting in increased risk factors in those domains not addressed.

Implications and Recommendations for Future Work

The process of finding evidence for program implementation in schools can be timeconsuming, but if school social workers want to effect change, it is important for them to be able to critically review available programs and continue to add to the evaluation database. In 2001 the Office of the Surgeon General found that of programs evaluated, over 50 percent were shown to be ineffective and caused some harm. In this review, out of 246 programs, only one appeared to meet all criteria. Undoubtedly, other programs are being implemented successfully in schools but were not included because they are in need of evaluation and dissemination. Even some programs touted as best practice in some fields have yet to be evaluated (Catalano et al., 1998;

This is the author's manuscript of the article published in final edited form as:

Gentle-Genitty, C. (2009). Best Practice Program for Low-Income African American Students Transitioning from Middle to High School. Children \& Schools, 31(2), 109-117. https://doi.org/10.1093/cs/31.2.109 
Office of the Surgeon General, 2001). Although STEP appears to hold the most promise, clearly more work is needed to assess the other "best practice” programs with more rigorous methods to see whether they work across different populations.

Furthermore, there was little information available about cost on best practice Web sites. On the surface, STEP would appear to be low cost as it does not entail new infrastructure, new curriculum, or new hiring. There may, however, be costs that were not obvious to the reviewer. More evaluations should include information on costs and cost-effectiveness and cost benefitsparticularly given the economic environment.

Closing the achievement gap and encouraging the school success of African American students is an important goal, and addressing the period of transition to high school is a key aspect of meeting that goal. This review used databases that are readily available to school social workers in the field, and the process of review required no statistical expertise. Although this is not the most rigorous form of systematic review, it is an accessible method for the practitioner and can result in better choices regarding selection of best practices.

This is the author's manuscript of the article published in final edited form as:

Gentle-Genitty, C. (2009). Best Practice Program for Low-Income African American Students Transitioning from Middle to High School. Children \& Schools, 31(2), 109-117. https://doi.org/10.1093/cs/31.2.109 


\section{References}

Akos, P., \& Galassi, J. P. (2004). Gender and race as variables in psychosocial adjustment to middle and high school. Journal of Educational Research, 98(2), 102-108.

Alspaugh, J. W. (1998). Achievement loss associated with the transition to middle school and high school. Journal of Educational Research 92(1), 20-25.

Barton, P. E. (2005). One-third of a nation: Rising dropout rates and declining opportunities. Policy Information Report. Policy Information Center Educational Testing Services. Retrieved June 25, 2006, from http:www.ets.org/research/pic

Blyth, D. A., Simmons, R. G., \& Bush, D. M. (1978). The transition into early adolescence: A longitudinal comparison of youth in two educational contexts. Sociology of Education, $51,149-162$.

Catalano, R. F., Berglaund, H. L., Ryan, J.A.M., Lonczak, H. S., \& Hawkins, J. D. (1998). Positive youth development in the United States: Research findings on evaluations of positive youth development programs. Retrieved March 16, 2006, from: http://aspe.hhs.gov/hsp/PositiveYouthDev99/chapter1.htm

Catalano, R. F., Loeber, R., \& McKinney, K. (1999). School and community interventions to prevent serious and violent offending. Washington, DC: US Department of Justice, Office of Justice Programs, Office of Juvenile Justice and Delinquency Prevention.

Cashin, S. (2004). The failures of integration: How race and class are undermining the

This is the author's manuscript of the article published in final edited form as:

Gentle-Genitty, C. (2009). Best Practice Program for Low-Income African American Students Transitioning from Middle to High School. Children \& Schools, 31(2), 109-117. https://doi.org/10.1093/cs/31.2.109 
American dream. New York: Public Affairs.

Clark, M. L. (1991). Social identity, peer relations, and academic competence of African American adolescents. Education and Urban Society, 24(1), 41-52.

Conduct Problems Prevention Research Group. (2002). Evaluation of the first 3 years of the fast track prevention trial with children at high risk for adolescent conduct problems. Journal of Abnormal Child Psychology, 30(1), 19-35.

Eccles, J. S., Lord, S. E., Roeser, R. W., Barber, B. L., \& Jozefowicz, D.M.H. (1999). The association of school transitions in early adolescence with developmental trajectories through high school. In J. Schulenberg, J. L. Maggs, \& K. Hurrelmann (Eds.), Health risks and developmental transitions during adolescence (pp.283-320). New York: Cambridge University Press.

Evidence for Policy and Practice Information Center (EPPI-Centre). (March, 2007). EPPICentre methods for conducting systematic reviews. London: EPPI-Centre, Social Science Research Unit, Institute of Education, University of London. Retrieved December 30, 2008, from http://eppi.ioe.ac.uk/cms/Default.aspx?tabid=89\&language=en-US

Felner, R. D., Brand, S., Adan, A. M., Mulhall, P. F., Flowers, B., Sartain, B., \& DuBois, D. L. (1993). Restructuring the ecology of the school as an approach to prevention during school transitions: Longitudinal follow-ups and extensions of the school transitional environment project. Prevention in Human Services, 10(2), 103-136.

This is the author's manuscript of the article published in final edited form as:

Gentle-Genitty, C. (2009). Best Practice Program for Low-Income African American Students Transitioning from Middle to High School. Children \& Schools, 31(2), 109-117. https://doi.org/10.1093/cs/31.2.109 
Fraser, M. W. (Ed.). (2004). Risk and resilience in childhood: An ecological perspective (2nd ed.). Washington, DC: NASW Press.

Geenen, S., Powers, L. E., \& Lopez-Vasquez, A. (2001). Multicultural aspects of parent involvement in transition planning. Exceptional Children, 67(2), 265-282.

Gentle-Genitty, C. (2008). Impact of schools’ social bonding on chronic truancy: Perception of middle school principals. Unpublished doctoral dissertation, Indiana University,.

Gibbs, L., \& Gambrill, E. (1999). Critical thinking for social workers: Exercises for the helping profession (2nd ed.). Thousand Oaks, CA: Pine Forge Press.

Gutman, M. L., \& Midgley, C. (2000). The role of protective factors in support of the academic achievement of poor African American students during the middle school transition. Journal of Youth and Adolescence, 29, 223-248.

Hale-Benson, J. E. (1986). Black children: Their roots, culture, and learning styles (2nd ed.). Baltimore: John Hopkins University Press.

Huang, B., Kosterman, R., Catalano, R. F., Hawkins, J. D., \& Abbott, R. D. (2001). Modeling mediation in the etiology of violent behavior in adolescence: A test of the social development model. Criminology 39(1), 75-107.

Irvine, J. J. (1990). Black students and school failure: Policies, practices and prescriptions. New York: Greenwood.

Johnstone, K. (2002). The transition to high school: A journey of uncertainty. Retrieved

This is the author's manuscript of the article published in final edited form as:

Gentle-Genitty, C. (2009). Best Practice Program for Low-Income African American Students Transitioning from Middle to High School. Children \& Schools, 31(2), 109-117. https://doi.org/10.1093/cs/31.2.109 
March 7, 2006, from http://www.aare.edu.au/02pap/joh02562.htm

Legters, N. E., \& Kerr, K. (2001). Easing the transition to high school: An investigation of reform practices to promote ninth grade success (Civil Rights Project at Harvard University's Graduate School of Education and Achieve, Inc.). Cambridge, MA: Johns Hopkins University.

Mizelle, N. B. (1999). Helping middle school students make the transition into high school. ERIC Digest [Electronic Source]. Retrieved March 7, 2006, from http://www.spannj.org/BridgeArchives/helping_middle_school_students_m.htm

National Center on Youth Transition. (2006). Promising programs categories. Tampa, FL: Louis de La Parte Florida Mental Health Institute - University of South Florida. Retrieved March 28, 2006, from http://ntacyt.fmhi.usf.edu/promisepractice/index.cfm

Newman, B. M. (2000). The transition to high school for academically promising, urban, lowincome African American youth. Retrieved March 7, 2006, from http://www.findarticles.com/p/articles/mi_m2248/is_137_35/ai_62958275/print (pp.117).

Office of Juvenile Justice Delinquency Prevention. (n.d.). Model Programs. Washington, DC: Author. Retrieved January 20, 2006 from http://www.dsgonline.com/mpg2.5/mpg_index.htm

Office of the Surgeon General. (2001). Youth violence: A Report of the Surgeon General (chapter 5). Retrieved March 22, 2005, from:

This is the author's manuscript of the article published in final edited form as:

Gentle-Genitty, C. (2009). Best Practice Program for Low-Income African American Students Transitioning from Middle to High School. Children \& Schools, 31(2), 109-117. https://doi.org/10.1093/cs/31.2.109 
http://www.mentalhealth.samhsa.gov/youthviolence/surgeongeneral/SG_Site/summary.as p\#PreventingYouthViolence

Osterman, K. (2000). Students' need for belonging in the school community. Review of Educational Research, 70, 323-367.

Phillips, A. (2006). Crisis deepens among young African American men. Retrieved July 2006, from http://www.voanews.com/english/archive/2006-03/2006-03-28voa62.cfm?rend

Rice, J. K. (2001). Explaining the negative impact of the transition from middle to high school on student performance in mathematics and science. Educational Administration Quarterly, 37, 372-400.

Richart, D., Brooks, K., \& Soler, M. (2003). Unintended consequences: The impact of zero tolerance and other exclusionary polices on Kentucky students. Building Blocks for Youth. Retrieved May 20, 2007, from http://www.buildingblocksforyouth.org/kentucky/kentucky.html

Roderick, M. (2003). What's happening to the boys? Early high school experiences and school outcomes among African American male adolescents in Chicago. Urban Education, 38, 538-607.

This is the author's manuscript of the article published in final edited form as:

Gentle-Genitty, C. (2009). Best Practice Program for Low-Income African American Students Transitioning from Middle to High School. Children \& Schools, 31(2), 109-117. https://doi.org/10.1093/cs/31.2.109 
Seidman, E., Allen, L., Aber, J. L., Mitchell, C., \& Feinman, J. (1994). The impact of school transitions in early adolescence on the self-system and perceived social context of poor urban youth. Child Development, 65(1), 507-522.

Smith, C., Lizotte, A., Thornberry, T. \& Krohn, M. (1995). Resilient youth: Identifying factors that prevent high risk youth from engaging in delinquency and drug use. In J. Hagan (Ed.) Current perspectives on aging and the life cycle, Vol. 4. Greenwich, CT: JAI Press.

Smith, J. B. (1997). Effects of eight-grade transition programs on high school retention and experiences. Journal of Educational Research, 90(3), 144-152.

Taylor, A. R. (1991). Social competence and the early school transition: Risk and protective factors for African-American children. Education and Urban Society, 24(1), 15-26.

Wattenberg, W. W. (1974). Today’s junior high students. In R. R. Leeper (Ed.), Middle school in the making (pp. 12-15). Washington, DC: Association for Supervision and Curriculum Development.

Weldy, G. R. (1995). Critical transitions: School in the middle. Educational Journal, 4(3), 4-7.

\section{Author}

Carolyn Gentle-Genitty, PhD, is assistant professor, School of Social Work, Indiana University, 902 West New York Street, ES 4145, Indianapolis, IN 46202.

She is also a national trainer for Aftercare for Indiana through mentoring (AIM), an advocate for

This is the author's manuscript of the article published in final edited form as:

Gentle-Genitty, C. (2009). Best Practice Program for Low-Income African American Students Transitioning from Middle to High School. Children \& Schools, 31(2), 109-117. https://doi.org/10.1093/cs/31.2.109 
student engagement from middle school to college, and a Preparing Future Faculty Mentor; email: cgentleg@iupui.edu. An earlier version of this article was presented at the Communities Aligned Toward Children’s Health (CATCH-Indiana) Midwest Regional Conference, November 30, 2006, Indianapolis.

Accepted January 7, 2009

This is the author's manuscript of the article published in final edited form as:

Gentle-Genitty, C. (2009). Best Practice Program for Low-Income African American Students Transitioning from Middle to High School. Children \& Schools, 31(2), 109-117. https://doi.org/10.1093/cs/31.2.109 
Table 1: Evaluation of Best Practice Programs, Using Inclusion Criteria

\begin{tabular}{|c|c|c|c|c|c|c|c|c|}
\hline Program & $\begin{array}{l}\text { : } \\
\stackrel{0}{0} \\
0\end{array}$ & 声 & 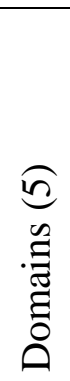 & 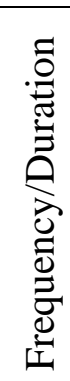 & 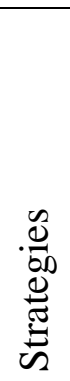 & 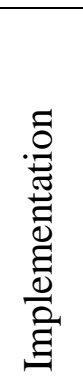 & 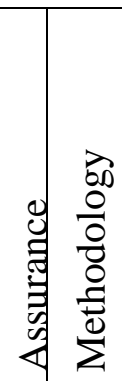 & 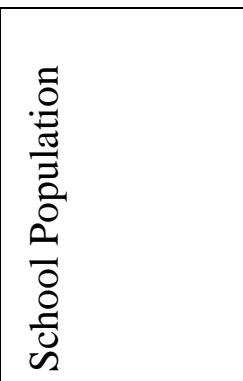 \\
\hline $\begin{array}{l}\text { School Transitional } \\
\text { Environmental Program }\end{array}$ & $\sqrt{ }$ & $\sqrt{ }$ & 5 & $\sqrt{ }$ & $\sqrt{ }$ & $\sqrt{ }$ & $\sqrt{ }$ & $\begin{array}{l}\text { Elementary/ } \\
\text { Middle }\end{array}$ \\
\hline $\begin{array}{l}\text { Skills, Opportunity and } \\
\text { Recognition }\end{array}$ & $\sqrt{ }$ & $\sqrt{ }$ & 4 & $\sqrt{ }$ & $\sqrt{ }$ & $\sqrt{ }$ & $\sqrt{ }$ & Elementary \\
\hline $\begin{array}{l}\text { Positive Action } \\
\text { Through Holistic } \\
\text { Education }\end{array}$ & $\sqrt{ }$ & & 4 & & $\sqrt{ }$ & & $\sqrt{ }$ & $\begin{array}{l}\text { Elementary/ } \\
\text { Middle }\end{array}$ \\
\hline Fast Track & $\sqrt{ }$ & $\sqrt{ }$ & 4 & $\sqrt{ }$ & $\sqrt{ }$ & & $\sqrt{ }$ & Kindergarten \\
\hline
\end{tabular}

This is the author's manuscript of the article published in final edited form as:

Gentle-Genitty, C. (2009). Best Practice Program for Low-Income African American Students Transitioning from Middle to High School. Children \& Schools, 31(2), 109-117. https://doi.org/10.1093/cs/31.2.109 